\title{
MAJAPAHIT DALAM LINTAS PELAYARAN DAN PERDAGANGAN NUSANTARA*
}

\author{
Bambang Budi Utomo \\ (Pusat Penelitian dan Pengembangan Arkeologi Nasional)
}

\begin{abstract}
Majapahit has been known as agrarian and maritime kingdom as well, with a territory covered almost as wide as the nowadays Republic of Indonesia region, excluding part of Papua and West Java (the Sundanese Kingdom). This was the condition after Gajah Mada well-known vow, the Palapa.

Long before Mahāpatih Gajah Mada spoke his vow, from the year 1292 CE inscription of Camundi one's learned that the consecration of the statue of Bhattari Camundi during the time of Śrī Mahārāja Kěrtanāgara from Sinhasāri was a token of his success in bringing all the areas and many islands around under his power. And that means that the idea of expanding the Java mandala had been managed by Śri Mahārāja Kerrtanāgara since the $1270-s$ before the inscription of Camundi was established.

Based on available written sources (scripts and inscriptions) and being compared to Sinhasāri manchala expansion, regions that were under Majapahit's authority covered only parts of Central Java, East Java, Madura, Bali and Sumbawa.

Majapahit's power was very depended on the services of the coastal ports such as Kambangputih, Siddhayu, Gresik, Surabhaya, and Canggu. And as to it Majapahit established powerful navy arms to secure the Majapahit waters in the Java Sea.

The Babad Laserm mentioned Lasĕm to be the port where Rājasawarddhana (Bhre Matahun) warships anchored. Rājasawarddhana was the ruler of Laserm who happened to be Hayam Wuruk's relatives. All these warships were assumed to protect Majapahit's waters in the Java Sea.
\end{abstract}

\section{PENGANTAR}

Hipotesa tentang luasnya wilayah Kerajaan Majapahit yang hampir seluas Indonesia sekarang, demikian "merasuk" dan dipercaya oleh sebagian masyarakat Indonesia. Akibat dari hipotesa yang kurang didukung

* Makalah yang dipresentasikan dalam Lokakarya Sehari "Mencari Bentuk Kapal Majapahit" yang diselenggarakan atas kerjasama Direktorat Jenderal Sejarah dan Purbakala (Departemen Kebudayaan dan Pariwisata), Japan-Majapahit Association, dan Komunitas Peduli Majapahit. Jakarta, 29 Juni 2009.

Berkala Arkeologi Tafun XXXX Edisi No. 2 /November 2009 
oleh data yang kuat ini, timbul anggapan bahwa Majapahit adalah kerajaan maritim yang mempunyai angkatan laut yang kuat. Kapal-kapalnya menguasai jalur-jalur pelayaran di Nusantāra. Kecuali Sunda (Jawa bagian barat) yang berada di satu pulau dengan Majapahit, beberapa daerah lain masuk dalam wilayah Kerajaan Majapahit.

Untuk "meluruskan" hipotesa yang sudah terlanjur berkembang tersebut, dalam makalah ini akan dikemukakan beberapa persoalan yang berkenaan dengan wilayah Majapahit, dan pelabuhan-pelabuhan penting yang berada di wilayah Majapahit. Kajian ini diperoleh dari sumber-sumber sejarah yang berupa prasasti maupun naskah. Sementara itu data mengenai teknologi perkapalan, baik data arkeologis berupa data temuan runtuhan kapal/perahu dari abad ke-13-15, relief bangunan, maupun dari data prasasti dan naskah kuna, hingga kini nyaris tidak ada atau belum ditemukan.

\section{USAHA PENYATUAN NUSANTARA}

Patih amangkubhumi Gajah Mada Patih Amangkubumi tak mau menikmati istirahat, berkatalah Gajah Mada: "sesudah kalah Nusāntara, saya menikmati istirahat, sesudah kalah daerah Gurun, Seran, Tañjung Pura, Haru, Pahang, Dompo, Bali, Sunda, Palembang, Tumasik, waktu itulah saya istirahat" (Padmapuspita 1966: 52).

Demikianlah isi Sumpah Palapa yang diucapkan oleh Mahāpatih Gajah Mada dari Kerajaan Majapahit seperti yang dikutip dari Kitab Pararaton. Sumpah ini diucapkan di hadapan Tribhūwanottunggadewi Jayawisnuwarddhanī (1328-1372). Atas dasar sumber Pararaton dan penyebutan nama-nama tempat di Nusāntara dalam Nāgarakĕrtāgama (Pigeaud 1960: 1), sebagian besar di antara kita percaya bahwa luas wilayah Kerajaan Majapahit nyaris

seluas Republik Indonesia sekarang.

Sebagai "konsekuensi" dari anggapan tersebut tentu timbul pertanyaan seberapa besar angkatan laut Majapahit kala itu? Sementara itu Majapahit baru selesai menumpas beberapa pemberontakan yang terjadi di Tanah Jawa (kawasan inti Majapahit), seperti pemberontakan di Saděng dan Keța pada tahun Foto 1: Prasasti Wadu Tunti 1331. ${ }^{1}$ Apakah mungkin Majapahit dapat menaklukan daerah-daerah yang jauh dari pusat pemerintahannya? Memang beberapa sumber sejarah, baik

1 Nāgarakērtāgama 49: 3 Tahun Śaka api memanah ari (1253). Sirna musuh di Saděng (Slamet Mulyana 2006: 371). 
dari Majapahit maupun daerah "taklukan" menyebutkan tentang penaklukan seperti itu. Naskah Rāja Purara (Kidung Pasunggrigis), misalnya, menyebutkan tentang penaklukan Bali pada tahun 1343 (Ketut Ginarsa 1977: 2765) dan Prasasti Wadu Tunti menyebutkan tentang penaklukan Kerajaan Kapalu di Sumbawa pada sekitar tahun $1343 .{ }^{2}$ Namun di tempat-tempat lain yang daftar namanya tercantum dalam Nāgarakĕrtāgama, sumber sejarah seperti itu nyaris tidak ada. Kalaupun ada, hanya bersifat oral yang diceriterakan dari mulut ke mulut yang pada akhirnya banyak terjadi penyimpangan dan pada akhirnya hilang. ${ }^{3}$

Semacam bukti arkeologis juga ditemukan di beberapa situs di luar Jawa. "Bukti" arkeologis itu antara lain berupa tembikar dalam bentuk kendi yang oleh para pakar disebut dengan istilah "kendi Majapahit" dengan ciri mempunyai payungan dan dibuat dari tanah liat halus yang berwarna merah. Kendi semacam ini ditemukan di Situs Muara Jambi (Jambi), Ketapang (Kalimantan Barat) dan

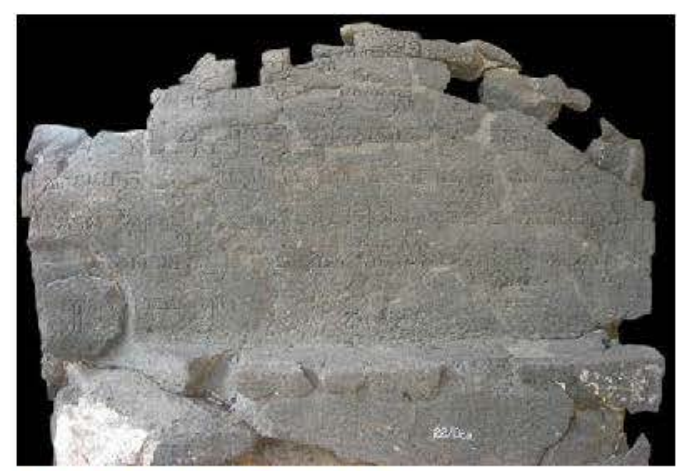
Foto 2: Prasasti Camundi Bontobontoa (Sulawesi Selatan).

Dengan bukti semacam ini beberapa pakar menduga bahwa daerah tersebut merupakan salah satu bagian dari wilayah Majapahit.

Ada pendapat yang menyatakan bahwa persatuan dapat terwujud apabila ada ancaman dari luar. Beberapa puluh tahun sebelum Mahāpatih Gajah Mada bersumpah untuk menyatukan Nusāntara di bawah Majapahit, Mahārāja Kěrtanāgara dari Kerajaan Sinhasāri juga berniat menyatukan Nusāntara. Hal ini dianggap penting untuk menghadapi ancaman serangan Khubilai Khan dari Kerajaan Mongol. Dalam prasasti yang dipahatkan pada bagian belakang arca Camundi (1292 Masehi) dari Desa Ardimulyo yang dikeluarkan oleh Mahārāja Kèrtanāgara terkandung gagasan perluasan cakrawāla mançala ke luar pulau Jawa yang meliputi daerah seluruh dwipāntara. Dalam prasasti itu dikatakan bahwa arca Bhatțari Camunḍi ditahbiskan pada waktu Śrī Mahārāja Kěrtanāgara menang di seluruh

2 Prasasti ini ditemukan di sebelah arat Teluk Bima pada daerah yang berbukit di kaki timur gunung Tambora. Tidak terdapat angkatahun, namun berdasarkan gambar manusia yang penggambarannya seperti wayang dan bentuk aksaranya, dapat diduga berasal dari sekitar pertengahan abad ke-14 hampir bersamaan waktunya dengan penyerangan Bali pada tahun 1343. (Atmodjo 1994: 2-3). Prasasti ini untuk pertama kalinya dibaca pada tahun 1983.

3 Di beberapa tempat di Nusantara banyak beredar kisah yang menceriterakan tentang adanya makam Gajah Mada, seperti di Lampung dan Pulau Buton. Ceritera semacam ini terjadi di kalangan penduduk lokal yang memberi "bumbu" pada sebuah tinggalan semacam makam. 
wilayah dan menundukkan semua pulau-pulau yang lain (Damais 1955: 151-153).

Dalam usahanya menyatukan Nusāntara, Śrī Mahārāja Kěrtanāgara tidak selalu menggunakan kekuatan bersenjata. Ketika melakukan Ekspedisi Pamalayu, misalnya, ia menghadiahkan arca Amoghapāśa kepada penguasa Mālayu sebagai tanda persahabatan. ${ }^{4}$ Mengenai pengiriman arca, tercantum dalam Prasasti Dharmmāśraya (Krom 1916: 306-339) yang isinya sebagai berikut:

"Pada tahun 1208 Śaka arca Amoghapāśa dengan keempatbelas pengiringnya dan saptaratna dibawa dari Bhūmi Jawa ke Swarnnabhūmi untuk ditempatkan di Dharmmāśraya sebagai punya Śrī Wiśwarūpakumāra. Yang diperintahkan oleh Śrī Mahārājādhirāja Kĕrtanāgara untuk mengiringkan arca tersebut ialah Rakryān Mahāmantri Dyaḥ Adwayabrahma, Rakryān Sirikan Dyaḥ Sugatabrahma, Samgat Payānan Hañ Dipangkaradāsa, dan Rakryān Dmuñ Pu Wira. Seluruh rakyat Mālayu dari keempat kasta bersuka cita, terutama rajanya, Śrīmat Tribhūwanarāja Mauliwarmmadewa".

Maksud Pengiriman arca itu jelas menunjukkan bahwa Sinhasāri tidak bermaksud menguasai Mālayu seperti tersirat dalam kalimat "Seluruh rakvat Mālavu dari keempat kasta bersuka cita, terutama rajanva, Śrīmat Tribhūwanarāja Mauliwarmmadewa". Mungkin maksud sinhasān adalah mengajak beraliansi untuk menghadapi serangan tentara Mongol yang datang dari utara. Dengan demikian, perlu diingat bahwa gagasan untuk menyatukan Nusāntara sudah mulai tumbuh jauh sebelum Gajah Mada mengucapkan sumpah Palapa-nya.

Dari kedua contoh tersebut (Majapahit dan Sinhasāri), jelas bahwa untuk memenuhi keinginan penyatuan Nusāntara diperlukan sarana angkutan laut dan tentara yang kuat. Tentu saja harus ada alasan yang kuat sebelum niatan tersebut dilontarkan dan dilaksanakan. Seperti halnya Kerajaan Sinhasāri yang berusaha mengantisipasi serangan dari Khubilai Khan setelah sebelumnya mendapat peringatan dengan dikirimnya utusan Mongol ke Sinhasāri pada tahun 1280 dan 1281.

Sumber sejarah yang menyebutkan perluasan cakrawāla mançala ke luar pulau Jawa oleh Śrī Mahārāja Kěrtanāgara itu cukup valid dan kuat. Ada sumber Prasasti Camuṇ̣i yang ada di Jawa, Prasasti Dharmaśrāya yang ada di Sumatra (Mälayu), dan sumber naskah Pararaton dan Nāgarakërtāgama. Sumber-sumber sejarah tersebut saling mendukung dan mengisi. Bagaimana halnya dengan Majapahit dengan sumpah Palapa-nya Gajah Mada? Apa alasannya sampai mengucapkan sumpah hendak menyatukan Nusāntara?

4 Beberapa pakar menginterpretasikan kata pamalayu sebagai usaha penaklukan Sinhasāri atas Mālayu. Menurut saya interpretasi ini kurang tepat karena dalam Prasasti Dharmaśrāya tidak ada indikasi informasi pemaksaan agar Mālayu tunduk pada Sinhasāri.

Berkala Arkeologi Tafun XXXX Edisi No. 2 / November 2009 
Kalau berdasarkan bukti-bukti yang masih terbatas, jelas bahwa wilayah Majapahit tidak seluas apa yang diduga oleh banyak orang. Berdasarkan sumber sejarah yang sampai kepada kita, wilayah kekuasaan kerajaan Majapahit hanya meliputi sebagian Jawa Tengah, Jawa Timur, Madura, Bali, sampai Sumbawa. Di dalam wilayah ini terdapat 21 negara daerah yang masing-masing diperintah oleh Paduka Bhatțara. Negara daerah itu antara lain Mataram, Pajang, Lasĕm, Kadiri, Lumajang, Madura, Bali, dan Gurun.

Kitab Nāgarakērtāgama menyebutkan sekurang-kurangnya 60 nama tempat di Nusāntara mulai dari Sumatra hingga Maluku//rian ( Nāg. 13:1-2; 14:1-5). Juga nama-nama tempat yang terdapat di Semenanjung Tanah Melayu. Dalam struktur kewilayahan, tempat-tempat ini disebut desantara kacayya, yaitu tempat-tempat yang mendapat perlindungan dari Raja Majapahit. Tempat-tempat ini bukan merupakan daerah wilayah kekuasaan Majapahit. Persembahan upeti pada waktu-waktu tertentu kepada Raja Majapahit, tidak lain sebagai tanda terimakasih karena Raja telah melindungi, dan bukan sebagai tanda tunduk.

Negara asing yang mempunyai hubungan dengan Majapahit, antara lain Ayudhyapura, Dharmanagari, Marutma, Rajapura, Singanagari, Campa, Kamboja, dan Yawana ( $N a \bar{g}$. 15:1). Negara-negara yang ada di Asia Tenggara daratan ini menjalin hubungan politik dan perdagangan dengan Majapahit. Mereka disebut sebagai mitra satata (negara sahabat yang sama kedudukannya).

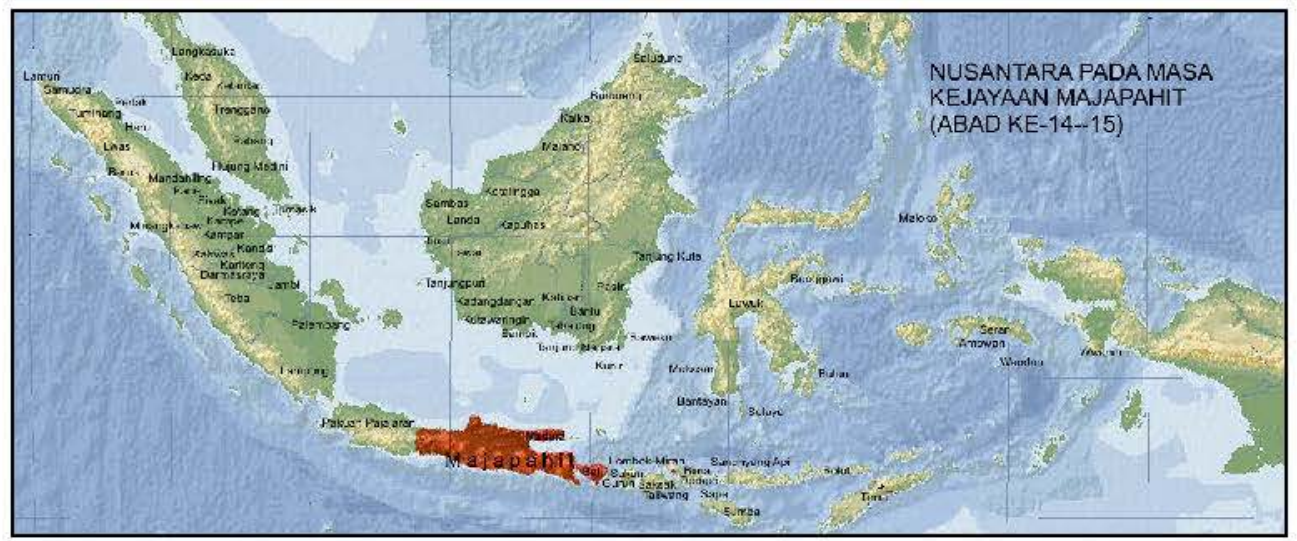

\section{PELABUHAN DI PANTAI UTARA JAWA}

Kalau direkonstruksi jalur-jalur pelayaran pada sekitar abad ke-7 hingga ke-9 Masehi berdasarkan berita-berita asing dan artefak asing yang ditemukan seperti keramik dan kaca, agaknya Jawa masih kurang ramai jika dibandingkan dengan Sumatra bagian timur. Namun kalau ditelusuri dari gaya seni arca Śailendra (abad ke-8 atau ke-9 Masehi) yang ditemukan di Jawa, Sumatra, dan Semenanjung Tanah Melayu, hubungan pelayaran di tempat-tempat tersebut cukup ramai dan intensif. Apalagi kalau ditelusuri 
dari perdagangan cengkeh dan pala yang hanya dihasilkan di kawasan timur Nusāntara (Maluku), tentunya pantai utara Jawa merupakan tempat yang strategis untuk pelabuhan. Posisi Jawa Timur terletak di tengah jalur pelayaran antara Sumatra dan Maluku.

Di Jawa Timur pada waktu itu, yang termasuk daerah inti kerajaan, ada beberapa kota pelabuhan, di antaranya pelabuhan Kambangputih (Tuban), Pajarakan, Gresik, Surabaya, dan Canggu. Jauh sebelum Majapahit, pada masa pemerintahan Raja Airlangga (abad ke-11 Masehi), di wilayah Jawa Timur telah dikenal pembagian fungsi pelabuhan sesuai dengan asal kedatangan kapal. Pelabuhan Hujungaluh yang merupakan pelabuhan sungai (Sungai Brantas) terletak di sekitar Mojokerto dan diatur untuk pelabuhan antarpulau, sedangkan pelabuhan Kambangputih yang letaknya di pesisir Tuban diatur untuk pelabuhan antarkerajaan ${ }^{5}$ (de Casparis 1958: 19-20).

Nama Hujungaluh disebutkan dalam Prasasti Kamalagyan yang berangka tahun 959 Śaka (1037 Masehi) sebagai kota pelabuhan dan perniagaan yang terpenting pada masa itu (Brandes 1913: 134-136). Kapalkapal niaga dan para saudagar dari pulau-pulau lain berdatangan ke Hujungaluh untuk berniaga ("....... maparahu samanghulu mangalap bhanda ri hujunggaluh tka rikang para puhawang para banyaga sangka ring dwipantara, samanunten $i$ hujunggaluh ........".). ${ }^{6}$ Pelabuhan ini terletak di daerah delta Brantas, kira-kira dekat kota Mojokerto sekarang. ${ }^{7}$

Tuban dengan Kambangputih sebagai pelabuhannya, juga merupakan tempat penting untuk disinggahi para saudagar. Tempat ini juga baik sebagai tempat untuk memperbaiki kapal-kapal niaga yang rusak karena dekat hutan jati sebagai bahan pembuat dinding lambung kapal. Pada awalnya Tuban merupakan pelabuhan yang ideal. Di pelabuhan ini banyak tinggal orang Tionghoa yang berasal dari Kanton dan Chang-chou (Groeneveldt 1960: 47). Namun pada akhir Majapahit, Tuban dikenal sebagai pelabuhan yang tidak aman. Sumber-sumber Tionghoa abad ke-15 menyebut pelabuhan Tuban sebagai tempat yang tidak aman, sehingga kapal-kapal saudagar Tionghoa menjauhinya. Mereka lebih suka ke Gresik dan Surabhaya. Kapal-kapal Tuban memaksa dengan kekerasan kapal-

5 Saudagar-saudagar asing yang berniaga di Kambaniputih berasal dari jauh. Menurut daftar yang terdapat beberapa kali dalam prasasti-prasasti Airlangga, antara lain saudagar dari India Utara, India Selatan Srilanka, Myanmar, Kamboja, dan Champa

6 Lihat prasasti Kamalagyan, baris 12-13.

7 Beberapa pakar memperkirakan pelabuhan Hujungaluh terletak disekitar kota Surabaya sekarang (Heru Soekadri 1975: 25-37), namun de Casparis (1958: 20) menempatkannya di sekitar kota Mojokerto, lebih hulu dari Kelagen (Kamalagyan). Dugaan ini didasarkan atas isi dari Prasasti Kamalagyan yang meyebutkan bahwa pengaturan sungai itu (Brantas) sangat menggembirakan para saudagar dari pulau-pulau lain yang sekarang dapat berlayar terus sampai ke Hujungaluh

Berkala Arkeologi Tafun XXXX Edisi No. 2 / November 2009 
kapal Tionghoa agar singgah di Tuban. Selanjutnya disebutkan bahwa Tuban sebagai sarang lanun (Groeneveldt 1960: 54).

Dari beberapa pelabuhan yang terdapat di pantai utara Jawa Timur, agaknya pelabuhan Gresik yang paling berperan. Peranan $\mathrm{Gresik}^{8}$ sebagai kota pelabuhan tidak dapat dipisahkan dari rangkaiannya dengan kota-kota pelabuhan lainnya di daerah pantai utara Jawa Timur, seperti Tuban (Tapan atau Tu-pan), ${ }^{9}$ Sidhayu, ${ }^{10}$ Hujungaluh (Jung-ya-lu atau Chung-kia-lu), dan Surabhaya. ${ }^{11}$ Lebih-lebih lagi jika kita lihat dari perspektif perkotaan dan permiagaan dari kurun waktu antara abad ke-11 sampai sekitar awal abad ke-16, Gresik dapat berkembang karena dukungan pelabuhan-pelabuhan lain serta keletakkan geografisnya yang lebih menguntungkan.

Sejalan dengan perkembangan perdagangan antara kawasan timur dan barat Nusāntara, di Jawa Timur pada masa Majapahit lahir pula beberapa kota pelabuhan. Kota-kota pelabuhan yang sudah ada berkembang lebih besar lagi. Kota-kota pelabuhan yang lahir pada masa Majapahit antara lain Canggu yang disebutkan dalam prasasti Selamandi II tahun 1318 Śaka (1396 Masehi) (Boechari 1985/1986: 86-87). dan prasasti Canggu (Trawulan I) tahun 1280 Śaka (1358 Masehi).

Berdasarkan hasil penelitian arkeologi di Situs Manyar (Gresik), permukiman di Gresik telah muncul pada sekitar abad ke-13 Masehi. Meskipun telah lama dihuni, nama Gresik baru muncul pada masa Majapahit. Dalam prasasti Karangbogem (Trawulan V) yang dikeluarkan oleh Bhre Lasĕm pada tahun 1387 Masehi, disebutkan adanya orang-orang dari Gresik ("hana ta kawulaningong saking gresik") yang diperkerjakan di perusahan tambak (perikanan) di Karangbogem. Menurut berita Tionghoa yang ditulis oleh Ma Huan (1433 Masehi), Gresik merupakan 'desa baru' yang dalam bahasa Mandarin disebut Ko-erh-hsi. Desa baru ini terletak di sebelah timur Tuban pada jarak sekitar setengah hari perjalanan.

Pada awalnya Gresik merupakan daerah pantai berpasir. Oleh orang-orang Tionghoa yang datang dari Tiongkok Tengah, antara tahun 1350 dan 1400 Masehi dibangun menjadi desa pemukiman yang baru. ${ }^{12}$

8 Nama Gresik disebutkan juga dalam Prasasti Karangbogem (Pigeaud 1960: 14) dan Kidung Sunda (Berg 1927: 1-16) bersama-sama dengan nama tempattempat lain di Jawa Timur.

9 Disebutkan dalam Serat Pararaton ["Pararaton (Ken Arok) of het Boek der Koningen van Tumapel en van Majapahit". Bewerkt door Prof. Dr. N.J. Krom, met medewerking van Prof. Mr. Dr. J.C.G. Jonker, H. Kraemer, en R.Ng. Poerbatjaraka. VBG LXII, 1920], dan Kidung Ranggalawe (Berg 1930)

10 Disebutkan juga di dalam Prasasti Karangbogem (Prasasti Trawulan V) dari tahun 1308 Śaka (1387 Masehi) bersama dengan Gresik (Pigeaud 1960: 122).

11 Merupakan beberapa tempat (pelabuhan yang berada di bawah kekuasaan Jawa (Sho-po). (Hirth, and W.W. Rochill 1966:83, 86). Nama Surabhaya disebutkan juga di dalam Prasasti Canggu (Boechari 1985/1986: 116-117) dan Kakawin Nāgarakĕrtāgama (Pigeaud 1960: 108-112)

12 L.C. Damais telah memberikan uraian panjang lebar mengenai arti dan asal-usul nama Gresik pada sebuah catatan dalam tulisannya "Etudes javanaises: I. Les 
Gresik berkembang pesat setelah tahun 1400 Masehi, dan ketika Ma Huan datang Gresik telah menjadi kota pelabuhan terbaik dan terpenting. Nama Gresik (Ko-erh-shi) disebut dalam Ying-yai Shĕng-lan bersama-sama dengan nama Tuban (Tu-pan), Surabhaya (Su-Iu-ma-i atau Su-erh-pa-ya), Canggu (Chang-ku), dan Majapahit (Man-che-po-i) (Mills 1970: 89-91). Penghuninya telah berkembang menjadi lebih dari seribu keluarga. Orang asing dari berbagai tempat banyak berdatangan ke tempat ini untuk berniaga. Berbagai jenis barang dagangan diperjual-belikan dalam jumlah yang banyak. Karena perdagangan ini penduduk kota Gresik menjadi sangat makmur (Mills 1970: 89-90).

Ma Huan menyebutkan barang-barang dagangan yang diperjualbelikan di pelabuhan Gresik diantaranya berupa emas dan batu-permata, dan berbagai jenis barang dagangan dari luar negeri. Dari kawasan timur Nusāntara diperjual-belikan pula rempah-rempah dari Maluku dan kayu cendana (sandawood) dari Timor yang ditukar dengan beras, tekstil, dan keramik (Schrieke 1957: 296; 1960: 25; Meilink-Roelofsz 1962: 109-110).

Menurut Tomé Pires dalam Suma Oriental, kota pelabuhan Gresik (Agracij, Agacij, atau Agraci) pada sekitar tahun 1512 merupakan bandar yang besar dan terbaik di seluruh Jawa, sehingga dijuluki "Permata dari Jawa" (Cortesão 1944: 192-194). Para pedagang asing dari Gujarat, Calicut, Benggala, Siam, Tiongkok, dan Liu-Kiu (Lequeos) sudah sejak lama berdatangan untuk berniaga di pelabuhan ini.

Gresik mempunyai dua bagian kota yang dipisahkan oleh sungai kecil. Kota pelabuhan Gresik dihubungkan di bagian utara dengan kota pelabuhan Sidhayu (Cedayo), dan di bagian selatan, dihubungkan dengan pelabuhan Surubhaya (Curubaia). Tomé Pires mengemukakan pula bahwa kota pelabuhan Gresik diperintah oleh dua penguasa yang saling bersaing. Penguasa ini yang satu bernama Adipati Jusuf (Pate Cucuf) menguasai sebagian besar wilayah, dan yang lainnya bernama Adipati Zainal (Pate Zeynall) menguasai bagian wilayah lainnya. Para penguasa Gresik ini juga merupakan saudagar-saudagar yang melakukan kegiatan pemiagaan dengan Maluku dan Banda. Kota pelabuhan Gresik pada waktu itu berpenduduk sekitar 6.000 sampai 7.000 orang.

\section{GALANGAN JUNK}

Hingga saat ini, data dan informasi mengenai teknologi perkapalan dari masa Majapahit (abad ke-14 hingga ke-15 Masehi) sangat kurang, bahkan dapat dikatakan nyaris tidak ada. Berdasarkan data yang terbatas itu, kita hanya dapat memperkirakan sampai seberapa tinggi teknologi

Tombes musulmanes datees de Tralaya", dalam BEFEO XLVIII (2), 1957: 353415 (catatan 30). Lihat pula terjemahannya dalam Bahasa Indonesia, di dalam: Epigrafi dan Sejarah Nusantara: Pilihan Karangan Louis-Charles Damais, Jakarta: EFEO/Puslit Arkenas, 1995:223-332 (catatan 30, hlm. 294-295). 
perkapalan pada masa itu. Perkiraan itu dapat direkonstruksi berdasarkan logika perkembangan teknologi perkapalan dari masa sebelumnya.

Data arkeologi maritim yang diperoleh dari beberapa situs dengan tinggalannya berupa runtuhan perahu/kapal seperti di Muara Kumpeh (Jambi), Sambirejo dan Tulung Selapan (Sumatra Selatan), dan Punjulharjo (Rembang, Jawa Tengah), menginformasikan pada kita bahwa teknologi perkapalan yang dikembangkan pada masa itu (abad ke-8-9 Masehi) adalah "teknik papan-ikat dan kupingan pengikat" (sewn-plank and lashed-lug technique). Teknologi ini merupakan tradisi di wilayah Asia Tenggara (Manguin 1985). Mengenai bentuknya, secara garis besar dapat diketahui dari beberapa relief perahu dan kapal yang dipahatkan pada relief-cerita Lalitawistara di Candi Borobudur (Lapian 1979: 95-103).

Penggunaan kapal sebagai wahana untuk mengarungi samudra dan menyeberangi pulau-pulau di Nusāntara sejak abad ke-8 Masehi, dan bahkan sejak sebelum tarikh Masehi, sudah dilakukan penghuni Nusāntara ini. Dengan teknologi "sederhana" mereka sudah dapat menyeberangi samudra. Sebut saja ketika Śrī Mahārājādhirāja Kĕrtanāgara mengirimkan arca Amoghapāśa dengan keempatbelas pengiringnya dan saptaratna dari Bhūmi Jawa ke Swamnabhūmi untuk ditempatkan di Dharmmāśraya, tentu menggunakan wahana kapal yang

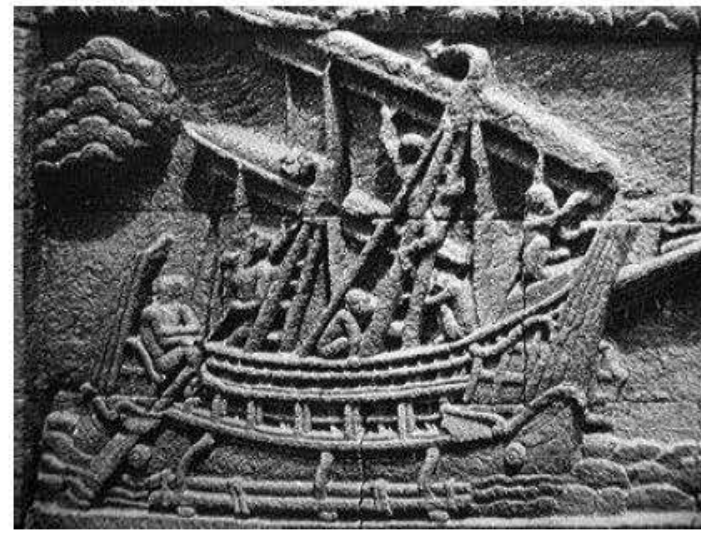

Foto 3: relief perahu pada candi Borobudur berukuran besar. Kalau dari masa

sebelum Majapahit sudah ada kemampuan mengarungi samudra, tidak mustahil pada masa Majapahit tentu juga demikian. Adanya pelabuhanpelabuhan di wilayah Majapahit merupakan suatu petunjuk. Data sejarah yang ditemukan di Lasĕm memberikan petunjuk yang masih awal tentang kepemilikan junk-junk perang oleh Majapahit.

Menuju arah barat dari rangkaian pelabuhan di pantai utara Jawa Timur terdapat pelabuhan tua yang bemama Lasěm. Nama Lasěm selama ini hanya dikenal dalam kakawin Nāgarakěrtāgama pupuh 5:1 sebagai tempat tinggal Bhre Lasěm (Śrī Rājasaduhitendudewi) yang dikunjungi Hayam Wuruk tahun 1354 Masehi. Informasi mutakhir tentang Lasěm ditemukan pada sekitar tahun 1980-an, yaitu Babad Lasěm. Babad Lasěm merupakan salinan dari isi babad bernama Pustaka Badrasanti yang ditulis oleh Kamzah, seorang bangsawan Lasěm yang hidup tahun 1825 (Satari 1985: 487-499). Dalam babad ini disebutkan beberapa nama pemukiman masa Bhre Lasěm memerintah pada tahun 1273 Saka. Tempat-tempat tersebut antara lain Kaeringan, Teluk Regol, Keraton Kryan, BonangBinangun, dan beberapa tempat keagamaan. 
Kaeringan merupakan pelabuhan yang telah ada sejak masa Dewi Indu (Bhre Lasěm, Śrī Rājasaduhitendudewi) berkuasa. Suaminya, Rājasawarddhana (Bhre Matahun) disebutkan menguasai junk-junk ${ }^{13}$ perang yang berada di tempat (pelabuhan) ini. Sampai masa Islam masuk di pantai utara Jawa, Kaeringan masih berfungsi sebagai pelabuhan. Dari masa ini disebutkan bahwa Pangeran Santikusumo ketika berusia 18 tahun, naik perahu dari tempat ini menuju Tuban.

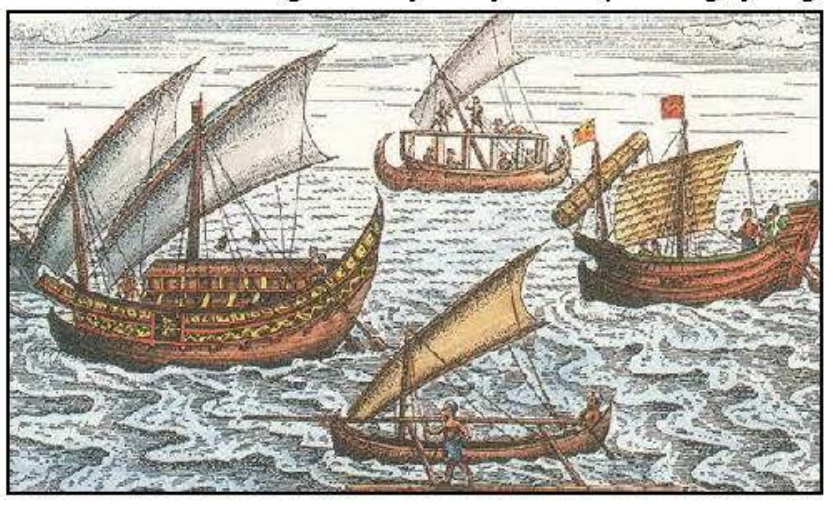

Pelabuhan lain di sekitar Lasěm adalah Teluk Regol. Di pelabuhan ini juga terdapat junk-junk perang yang dikuasai oleh Rājasawarddhana. Disebutkan juga berlabuhnya junk-junk Campa milik saudagar Bi Nang Un di Teluk Regol. Dari nama Bi Nang Un, nama Regol kemudian berubah menjadi Binangun, desa sekitar $4 \mathrm{~km}$ menuju arah timur Lasem. Letaknya di tepi teluk yang berair tenang.

Penelitian arkeologi di daerah Lasěm berhasil mengidentifikasikan nama-nama tempat yang disebutkan dalam Babad Lasěm (Rangkuti 1988: 11-12). Di Situs Kiringan yang dalam Babad Lasěm disebut Kaeringan terdapat tinggalan budaya yang berupa struktur bata, tembikar, keramik, matauang kepeng, dan bandul jaring; di Situs Binangun yang dalam Babad Lasěm disebut Pelabuhan Regol terdapat tinggalan budaya yang berupa sumur kuna, bata dan batu candi, keramik, dan manik-manik. Kedua situs tersebut letaknya di daerah pantai.

Secara geografis Lasěm memang menempati posisi yang strategis di antara Jepara dan Tuban. Dari sisi sumberdaya alam yang dekat hutan jati di kawasan pedalaman sangat memungkinkan untuk pembuatan/ perbaikan junk. Sumber-sumber Portugis dan Belanda menginformasikan bahwa Lasěm merupakan salah satu tempat di Jawa yang dipakai sebagai galangan kapal, bahkan merupakan pusat industri kapal. Kapal-kapal yang dibuat disini adalah kapal yang berukuran kecil khusus untuk berperang (Lapian 2008: 35). Keahlian ini mungkin sudah ada jauh sebelum kedatangan bangsa-bangsa Eropa ke Nusāntara. Seperti yang diberitakan

13 Kata "junk" atau "jung" sekurang-kurangnya sudah digunakan sejak pertengahan abad ke-14 sebagaimana tertulis dalam Kidung Sunda "...raja Sunda melancong dengan sebuah jong sasana". Jong ini sama seperti yang dibuat di negeri Tartar dan ditiru sejak perang oleh Wijaya (Berg 1927: 77). Tetapi Manguin berpendapat bahwa kata "junk" sudah dipakai untuk menyebut "kapal" pada prasasti abad ke-9 Masehi (Manguin 1985: 24) 
Babad Lasĕm bahwa Rājasawarddhana (Bhre Matahun) menguasai junkjunk perang yang berada di pelabuhan Kaeringan dan Teluk Regol.

Majapahit merupakan sebuah kerajaan agraris yang keletakkannya di Nusāntara di tengah jalur perdagangan/pelayaran antara bagian timur dan barat Nusāntara. Para saudagar dari timur Nusāntara membawa rempah-rempah (cengkeh dan Pala), sedangkan dari barat membawa hasil hutan (kapur barus, kemenyan, dan damar) dan produk dari Timur Tengah (kaca). Para saudagar ini bertemu di salah satu pelabuhan di wilayah Majapahit. Karena keletakkannya inilah Majapahit berusaha memonopoli perdagangan Nusāntara melalui pelabuhan-pelabuhannya di pantai utara Jawa bagian timur. Wajar jika para saudagar dari kerajaan-kerajaan kecil di Nusāntara memohon perlindungan pada Raja Majapahit sebagai desantara kacayya. ${ }^{14}$

Berdasarkan sumber Babad Lasẽm dan lokasi geografis Majapahit, dapat diperoleh gambaran bahwa Majapahit memang memerlukan junk-junk perang yang mungkin ukurannya lebih kecil tetapi mempunyai kelincahan yang tinggi. Junk-junk perang ini diperlukan untuk mengamankan perairan Majapahit di Laut Jawa dan pelabuhan-pelabuhannya di pantai utara Jawa seperti Lasĕm, Tuban (Kambangputih), Sidhayu, Gresik, Surabhaya, dan Canggu. Mengenai bentuk, apalagi teknologinya belum dapat diketahui dengan pasti karena hingga kini belum pernah ditemukan bukti runtuhannya.

\author{
Saudagar Tionghoa arungi lautan \\ Kota Lasem tempatnya merapat \\ Jangan cepat ambil simpulan \\ Sebelum ada bukti tepat \\ (Bambang Budi Utomo, Kerani Rendahan)
}

14 Bandingkan dengan perserikatan dagang Tamil yang dikenal dengan nama "Yang kelima ratus dari seribu arah". Perserikatan dagang Tamil di Asia jumlahnya cukup banyak, beberapa di antaranya Manigramam, Añjuvannnam, Ainnuarruvar, dan Valanjiyar. Mereka ini membayar pajak añcu-tunt-ayam dalam bentuk emas berdasarkan harga kasturi dengan obyeknya "(Setiap ... dari) kapalnya, nahkoda kapal, dan kevi' kepada Rajendracōla di India Selatan. Sebagai imbalannya Rajendracōla memberikan perlindungan kepada para saudagar Tamil.

Berkala Arkeologi Tafun XXXX Edisi No. 2 /November 2009 


\section{KEPUSTAKAAN}

Armando Cortesão, 1944, The Suma Oriental of Tomé Pires. An Account of the East, from Red Sea to Japan, written in Malacca and India in 1512-1515. Translated from Portuguese MS in the Bibliothèque de la Cambre des Députés, Paris, and edited by Armando Cortesão. London: Hakluyt Society, 2 vols, hlm. 192-194.

Atmodjo, M.M. Soekarto Karto, 1994, "Beberapa temuan prasasti baru di Indonesia", dalam Berkala Arkeologi Tahun XIV Edisi Khusus (Evaluasi Data dan Interpretasi Baru Sejarah Indonesia Kuna), hlm. 2-3. Yogyakarta: Balai Arkeologi Yogyakarta

Berg, C.C, 1927, "Kidung Sunda. Inleiding, tekst, vertaling en aantekeningen," dalam BKI 83: 77

1930, "Rangga Lawe, Middeljavaansche historische roman", dalam Bibliotheca Javanica, 1. Weltevreden

Boechari, 1985/1986, Prasasti Koleksi Museum Nasional, I. Jakarta: Museum Nasional, hlm.116-117

Brandes, J.L.A., 1913, "Oud-Javaansche Oorkonden", dalam VBG, LX:134136 (OJO LXI).

de Casparis, J.G., 1958, "Airlangga", Pidato Diucapkan pada Peresmian Penerimaan Djabatan Guru Besar dalam Mata Peladjaran Sedjarah Indonesia Lama dan Bahasa Sansekerta pada Perguruan Tinggi Pendidikan Guru Universitas Airlangga di Malang jang Diadakan di Malang pada Hari Saptu Tgl. 26 April 1958. Surabaja: Penerbitan Universitas

Damais, L.Ch., 1955, "Ètudes d'Épigraphie Indonésienne: IV. Discussion de la date des inscriptions", dalam BEFEO XLVII, hlm 151-153.

Groeneveldt W.P., 1960, Historical Notes on Indonesia and Malaya Compiled from Chinese Sources. Djakarta: Bhratara, hlm. 47.

Heru Soekadri, K., 1975, "Hujunggaluh Pendahulu Surabaya", dalam Bulletin Yapema: Berita IImu-ilmu Sosial dan Kebudayaan No. 6 Tahun-II April 1975, hlm. 25-37. Jakarta: Yayasan Perpustakaan Nasional. 
Hirth, F. and W.W. Rochill, 1966, Chau Ju-kua, His Work on Chinese and Arab Trade in Twelfth and Thirteenth Centuries, entitled Chu-fan-chi. Amsterdam: Oriental Press, hlm. 83, 86.

Ketut Ginarsa, 1977, "Ekspedisi Gajah Mada ke Bali", dalam MISI VII(1), hIm. 27-65.

Krom, N.J., 1916, "Een Sumatraansche Inscriptie van Koning Krtanagara", dalam VMKAWL, 5e serie, dl. II, hlm. 306-339

Lapian, A.B., 1979, "Pelayaran dalam Periode Sriwijaya", dalam PraSeminar Penelitian Sriwijaya hal. 95-103. Jakarta: Pusat Penelitian Purbakala dan Peninggalan Nasional.

Lapian, Adrian B., 2008, Pelayaran dan Perniagaan Nusantara Abad Ke-16 dan 17. Depok: Komunitas Bambu

Manguin, Pierre-Yves., 1985, "Late Mediaeval Asian Shipbuilding in the Indian Ocean: A Reappraisal." Dalam Moyen Orient et Océan Indien II (2): 24

Manguin, P.Y. 1985, "Sewn-plank craft of Southeast Asia: a prelimary review", Archeological Series 10. Greenwich: National Maritime Museum

Meilink-Roelofsz, M.A.P.,1962, Asian Trade an European Influence in the Indonesian Archipelago between 1500 and about 1630.'sGravenhage: Martinus Nijhoff, hlm. 109-110

Mills, J.V.G., 1970, Ma Huan, Ying-yai Sheng-lan. The Overall Survey of the Oceans's Shore, (1433). London: Hakluyth Society, hlm. 89-91

Padmapuspita, Ki J., 1966, Pararaton. Teks Bahasa Kawi, terjemahan Bahasa Indonesia. Jogjakarta: Taman Siswa.

Pigeaud, Th. G. Th., 1960, Java in the $14^{\text {th }}$ Century: A Study in Cultural History. The Nāgara-kërtāgama by Rakawi Prapañca of Majapahit, 1365 A.D. Vol. I. the Hague: Martinus Nijhoff

Rangkuti, Nurhadi, 1988, "Kajian arkeologi situs masa sejarah di Lasem: Pergeseran pusat kegiatan". Makalah dalam Diskusi IImiah Arkeologi VI. Jakarta 11-12 Februari 1988. Diselenggarakan oleh Ikatan Ahli Arkeologi Indonesia, Komda DKI Jakarta dan Jawa Barat. 
Satari, Soejatmi, 1985, "Caruban, Lasem: Suatu Situs Peralihan KlasikIslam", dalam Pertemuan IImiah Arkeologi III, hlm. 487-499. Jakarta: Pusat Penelitian Arkeologi Nasional.

Schrieke, B.J.O., 1957, Indonesian Sociological Studies, Part Two: Ruler and Realm in Early Java. The Hague/Bandung: W. van. Hoeve, hlm. 296; 1960

Schrieke, B.J.O., 1960, Indonesian Sociological Studies, Part One. The Hague: W. van Hoeve. Second Edition, hIm. 25

Slamet Mulyana, 2006, Tafsir Sejarah Nagara Kretagama. Jakarta: LkiS Yogyakarta 